\title{
Britain plays it cautious on animal-human transplants
}

IMAGE UNAVAILABLE FOR COPYRIGHT REASONS

Santer: Seeking to avoid conflicts of interest on review panels advising European Commission.

\section{Change for Europe's science committees}

[PARIS] Jacques Santer, president of the European Commission, said last week that responsibility for scientific advisory committees should be taken away from those departments of the commission whose interests could conflict with public health and consumer protection.

The proposal follows criticism of the way the commission has managed scientific advice in the bovine spongiform encephalopathy (BSE) crisis (see Nature 384, 8; 1996). The draft report of an inquiry by the European Parliament into the handling of BSE alleges that the existing arrangements have been a recipe for conflicts of interest.

Speaking before the parliament's inquiry committee on BSE, Santer said that he would ask his fellow commissioners to approve a reorganization under which the commission's scientific advisory committees would be regrouped into a single division of 'product safety'.

Santer suggested that this division might be attached to the directorate for consumer policy (DG 24). He also promised reforms to deal with the way in which members of advisory committees are nominated, and greater openness in the way they operate.

The aim, he said, is to achieve a "desirable" separation between scientific assessment and decision-making. The scientific veterinary committee, for example, would be removed from the powerful agriculture directorate, which has responsibility for drafting legislation and managing markets.

Santer also gave cautious backing to an earlier proposal by Franz Fischler, the agriculture commissioner, to create an independent European inspection agency (see Nature 384, 503; 1996).

The creation of a European equivalent of the US Food and Drug Administration (FDA) "should not be excluded", he said. However, in practice, Santer's proposed agency would be a far cry from a European FDA, as it would only have a staff of about a hundred inspectors.

DeclanButler
[LONDON] Britain has announced a temporary moratorium on xenotransplantation - the use of animal tissue for human surgery - in the light of continuing uncertainty about its safety, including the dangers of transferring viruses from animals to man.

The decision was announced last week in response to the report of a panel set up to study the ethics of xenotransplantation. The report drew particular attention to the potential threat of retroviruses, the genes for which could lie unexpressed in the genome of an animal whose organs are being used.

The most immediate impact of the decision could be a delay in clinical trials of the use in human transplants of pig hearts that have been genetically engineered to reduce the risk of rejection.

The ethics panel, chaired by Ian Kennedy, professor of medical law and ethics at Kings College in London, concluded that there were no ethical reasons why such experiments and eventually operations - should not eventually be carried out, echoing other reports including that from the US Institute of Medicine (see Nature 382, 197; 1996).

But it highlighted a number of issues which, it said, need to be addressed before such trials should go ahead. In addition to the virus threat, for example, it said a comprehensive statutory framework of regulation should be put in place to protect the interests of patients.

In response, Stephen Dorrell, the health secretary, announced last week that not only had the government accepted the panel's judgement on the scientific and ethical aspects of xenotransplantation, but it had also agreed to introduce legislation to ensure its proposals are legally enforceable.

Until the new legislation is passed, all research in the field will be monitored by a so-called Xenotransplantation Interim Regulatory Authority. Dorrell announced that this committee will be chaired by Lord Habgood, a former Archbishop of York who trained as a pharmacologist and is widely respected for his writings on the relationship between science and religion.

The need for a regulatory framework sharpened 18 months ago with the announcement by a Cambridge-based biotechnology company, Imutran, that it had successfully completed trials of the transplantation of transgenic pig hearts into monkeys (see Nature 377, 185; 1995).

It has also been stimulated by increasedknowledge about the nature of some of the potential difficulties, including the possible transmission of retroviruses. A team at the Institute for Cancer Research in London, for example, has been able to show that the genetic coding for two C-type retroviruses can be transmitted from pig tissue to human tissue, and that one of these is subsequently expressed in the human tissue.

Scientists working with Imutran and other companies are confident that the safety problems will not prove insurmountable. But it will be for the interim regulatory authority - or whatever succeeds it - to decide whether clinical trials can be carried out on humans before a complete picture of the potential dangers has been worked out. $\square$

\section{'German politicians break research pledge'}

[MUNICH] The heads of Germany's leading research organizations last week accused politicians of breaking a commitment to protect research against the pressures caused by the country's economic difficulties.

The scientists issued a statement arguing that neither the economic recession nor the cost of meeting criteria for a unified currency within the European Union justifies reducing investment in education and research, which are essential for economic recovery. It was sent to the federal research minister, Jürgen Rüttgers, and the prime minister of each German state.

The statement, Priorities for the Future, expresses a widespread disillusionment with national politics among German scientists. Its signatories include Wolfgang Frühwald, president of the Deutsche Forschungsgemeinschaft, and Hubert Markl, president of the Max Planck Society.

Despite frequently repeated promises by senior politicians, including Chancellor Helmut Kohl, that Rüttgers' ministry of education and research - which only three years ago was heralded as the 'ministry of the future' - would be selectively protected from financial cuts, it has suffered much greater cutbacks this year than other federal ministries (see Nature 384, 399; 1996).

The statement from the scientific leaders also argues that universities should be released from the constraints imposed by the federal 'framework' law (Hochschulrahmengesetz), whose reform is currently being debated (see Nature 384, 204; 1996). It calls for the law to be abandoned so that universities could choose their own students and set their own rules, allowing for real competition between them. 